\title{
Analysis of Mechanisms to Increase the Industrial Silicon Solar Cell Efficiency
}

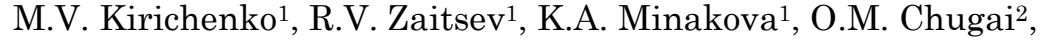 \\ S.V. Oleynick ${ }^{2}$, S.Yu. Bilyk ${ }^{1}$, B.O. Styslo ${ }^{1}$ \\ ${ }^{1}$ National Technical University "Kharkiv Polytechnic Institute», 2, Kyrpychova St., 61002 Kharkiv, Ukraine \\ 2 Zhukovsky National Aerospace University "Kharkiv Aviation Institute», 17, Chkalova St., 61000 Kharkiv, Ukraine
}

(Received 12 April 2021; revised manuscript received 09 December 2021; published online 20 December 2021)

Possibilities of increasing the efficiency by more than $20 \%$ for silicon photoelectric converters made in China have been investigated. It has been established by the method of computer simulation that the lifetimes of nonequilibrium charge carriers, which are $520 \mu \mathrm{s}$, realized in such photoelectric converters, do not limit the possibility of increasing their efficiency by more than $20 \%$. It has been shown that an increase in the photocurrent density to $43.1 \mathrm{~mA} / \mathrm{cm}^{2}$ leads to an increase in the efficiency to $20.1 \%$, and a decrease in the diode saturation current density to $3.1 \cdot 10^{-14} \mathrm{~A} / \mathrm{cm}^{2}$ leads to an increase in the efficiency to $20.4 \%$. Simultaneous change of these diode characteristics leads to an increase in the efficiency to $23.1 \%$. The paper proposes physical and technological approaches to increase the photocurrent density and reduce the diode saturation current density in ready-made photovoltaic converters. The study of the influence of operating temperature on the efficiency of crystalline silicon photoelectric converters has been carried out in the article. It has been shown that with increasing operating temperature the relative decrease in the efficiency of single-crystal devices is -0.7 relative $\% / C$, which is significantly higher than in the device structures of European production and due to non-traditional decrease in short-circuit current density. Mathematical modeling of the influence of light-emitting diode characteristics on the efficiency of crystalline silicon solar cells showed that a decrease in the efficiency of device structures with increasing operating temperature is due not only to an increase in diode saturation current density from $10^{-13}$ to $3 \cdot 10^{-13} \mathrm{~A}$, which is $300 \%$, but also by reducing the shunt resistance from 2.5 to $1.5 \mathrm{kOhm}$. A study of the effect of operating temperature on the diode saturation current showed that the height of the potential barrier in the studied silicon photovoltaic converters is $0.87 \mathrm{eV}$ due to the insufficient level of doping of the base material. The limited height of the potential barrier leads to an unconventional decrease in the shunt resistance with increasing operating temperature.

Keywords: Silicon, Photovoltaic converters, Solar energy, PV/T systems, Electrical parameters, Efficiency, Modeling, Optimization.

DOI: 10.21272/jnep.13(6).06026

PACS numbers: 78.55.Ap, 89.20.Bb

\section{INTRODUCTION}

The main problem of large-scale ground-based use of the most common solar cells (SCs) based on crystalline silicon is to ensure the competitiveness of the electrical energy generated by such device structures in comparison with traditional sources of electricity [1]. This can be achieved by reducing the cost of $1 \mathrm{~W}$ of peak power by increasing the conversion factor (efficiency) of solar energy and reducing the cost of their manufacturing technology [1].

At present, Western companies have developed and implemented design and technological solutions (DTSs) of SCs based on crystalline silicon with an efficiency of more than $20 \%$ in industrial production [2-4]. The implementation of such DTSs on an industrial scale requires the technical re-equipment of domestic electronic enterprises engaged in the industrial production of SCs based on crystalline silicon, through the purchase of expensive high-tech equipment that has no domestic analogues.

At present, as a result of a sharp increase in investments in production development, leading Chinese firms have reduced the cost of SC with an efficiency of $18 \%$ by more than 1.4 times, and in the next three years the cost will be reduced by another 1.3 times $[5,6]$. Thus, it is economically feasible to use Chinesemade Si-SCs as the initial device structures. At the same time, analysis of the efficiency of photoelectric conversion in such device structures should be considered an urgent task to study the possibility of increasing the efficiency of ready-made SCs made in China by over $20 \%$.

\section{METHODOLOGY OF THE EXPERIMENT}

In industrial conditions, when controlling the technological process by analytical processing of the light current-voltage characteristic (CVC), the output parameters of the SC are determined: open-circuit voltage $(U o c)$, short-circuit current density $(J s c)$, fill factor of the light CVC $(F F)$ and efficiency. However, these parameters represent the technical characteristics of the device, which do not have an unambiguous connection with the photovoltaic processes that determine the operation of the SC. Therefore, along with the output parameters, it is necessary to analyze the light diode characteristics that unambiguously determine the single-diode model of the SC [6]. These diode characteristics include the photocurrent density $\left(J_{P H}\right)$, diode saturation current density $\left(J_{0}\right)$, ideality coefficient $(A)$, shunting $\left(R_{S H}\right)$ and series $\left(R_{S}\right)$ resistance calculated per unit area of the SC. The theoretical light CVC implicitly describes the relationship between the efficiency and light diode characteristics of the SC [6]:

$$
J_{L}=-J_{P H}+J_{0}\left\{\exp \left[\frac{e\left(U_{L}-J_{L} R_{S}\right)}{A k T}\right]-1\right\}+\frac{U_{L}-J_{L} R_{S}}{R_{S H}},
$$


where $J_{L}$ is the load current density, $e$ is the electron charge, $k$ is the Boltzmann constant, $T$ is the solar cell temperature, $U_{L}$ is the load voltage drop.

By approximating the experimentally obtained values $I_{L}$ and $U_{L}$ by theoretical expression (1), it is possible to determine the output parameters, light diode characteristics and efficiency of the SC. Analytical processing of the light CVC of the investigated SCs was carried out using a PC according to the developed program. In accordance with the program, the analytical expression for the light CVC (1) is converted into the following expression:

$$
J_{L}=A_{0}-A_{1} U_{L}-A_{2} \exp \left(A_{3} U_{L}+A_{4} J_{L}\right),
$$

where $A_{0}=\frac{\left(J_{P H}+J_{0}\right) R_{S H}}{R_{S}+R_{S H}}, A_{1}=\frac{1}{R_{S}+R_{S H}}, A_{2}=\frac{J_{0} R_{S H}}{R_{S}+R_{S H}}, A_{3}=\frac{e}{A k T}$, $A_{4}=\frac{e R_{S}}{A k T}$

Using expression (2) and experimentally obtained values $J_{L}$ and $U_{L}$, by varying the values of the above coefficients $A_{0}, A_{1}, A_{2}, A_{3}, A_{4}$, the program performs the best approximation of the experimental data $I_{L}=I_{L}\left(U_{L}\right)$ curve described by the transformed theoretical expression (2). Usually, during analytical processing, the rootmean-square deviation does not exceed $10^{-8}$, which corresponds to a relative error in determining the output parameters and light diode characteristics at a level of no more than $1 \%$. After finding the specified coefficients that provide the best approximation, the output parameters of the SC are determined: $J_{S C}, U_{O C}$, $F F$, efficiency. The light diode characteristics $R_{S}, R_{S H}$, $A$ and $I_{0}$ are calculated according to the given coefficients $A_{0}, A_{1}, A_{2}, A_{3}, A_{4}$. The light CVC of the SC were measured using a laboratory stand, when the design structures were irradiated with a simulator of solar radiation in ground conditions with a luminous flux power of $100 \mathrm{~mW} / \mathrm{cm}^{2}$. A $1000 \mathrm{~W}$ halogen lamp connected to a stabilized power supply was used as a source that simulates solar radiation.

The efficiency of photovoltaic processes - generation, diffusion, drift, separation and collection of nonequilibrium charge carriers generated under the influence of light - essentially depends on their lifetime. Therefore, when analyzing the efficiency of the SC, we determined the lifetime of nonequilibrium charge carriers in the investigated device structures by the open-circuit voltage drop method [7].

Investigation of the spectral dependence of the quantum efficiency $Q(\lambda)$ allows you to analyze the integral efficiency of photovoltaic processes depending on the energy of the incident radiation [7]. Therefore, such studies are also necessary when optimizing the coefficient of thermal expansion (CTE) of SCs. There is a functional relationship between the short-circuit current $I_{S C}$ and the value of $Q(\lambda)$, described with a sufficiently large shunt resistance $R_{S H}$ by the ratio [7]:

$$
I_{S C}=e \int_{0}^{\lambda_{R E D}} Q(\lambda) \cdot N(\lambda) d \lambda-I_{D},
$$

where $\lambda$ is the light wavelength, $\lambda_{R E D}$ is the red border of the photoelectric effect, $N(\lambda)$ is the rate of arrival of photons on the SC surface, $I_{D}$ is the SC diode current.

In real conditions, the intensity of solar radiation arriving at the SC surface is such that at the observed value of the series resistance of the device structure $I_{D}<<I_{S C}$, therefore (3) is converted to the form:

$$
I_{S C}=Q(\lambda) \cdot N(\lambda) \text {. }
$$

The quantity $N(\lambda)$ included in (4) can be expressed in terms of the light intensity $I_{L I}(\lambda)$ [8], coming to the surface of the SC:

$$
Q(\lambda)=\frac{I_{S C}(\lambda) \cdot E(\lambda)}{e S \cdot I_{L I}(\lambda)}
$$

When studying the spectral dependence of the photoresponse, the SC was placed at the exit slit of a double monochromator, and the $I_{S C}$ was measured with a smooth change in the wavelength of the incident radiation with subsequent calculation of $Q(\lambda)$ by ratio (5). The light intensity $I_{L I}(\lambda)$ is a characteristic of the light source used, which was a $1000 \mathrm{~W}$ halogen lamp.

\section{RESULTS AND DISCUSSION}

\subsection{Experimental Studies of Industrial Samples of Silicon SCs}

For the study, the most effective industrial designs of SCs made in China were selected. The light CVCs of 10 device structures were measured. The results indicate that the efficiency is between 17.7 and $18.4 \%$ [9]. For the analysis, we chose the light CVC of a $\mathrm{SC}$ with a characteristic efficiency of $18.1 \%$ (Fig. 1, curve 1).

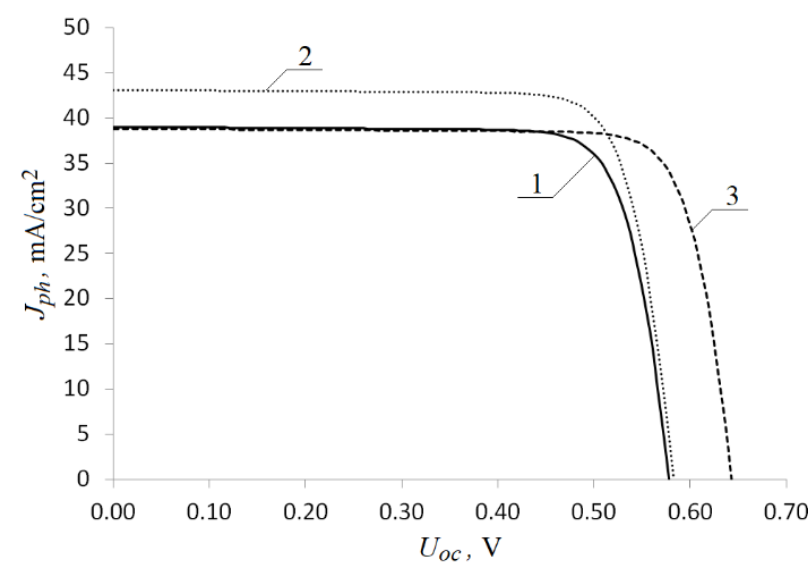

Fig. 1 - Light current-voltage characteristics:

$1-J_{P H}=39.0 \mathrm{~mA} / \mathrm{cm}^{2}, J_{0}=5.4 \cdot 10^{-13} \mathrm{~A} / \mathrm{cm}^{2}$, efficiency $=18.02 \%$ $2-J_{P H}=43.0 \mathrm{~mA} / \mathrm{cm}^{2}, J_{0}=5.4 \cdot 10^{-13} \mathrm{~A} / \mathrm{cm}^{2}$, efficiency $=20.02 \%$ $3-J_{P H}=39.0 \mathrm{~mA} / \mathrm{cm}^{2}, J_{0}=3.1 \cdot 10^{-14} \mathrm{~A} / \mathrm{cm}^{2}$, efficiency $=20.40 \%$

Analytical processing of the light CVC made it possible to determine the output parameters and light diode characteristics of the SC [10,11] (Table 1).

Studies on the output parameters and light diode characteristics were complemented by studies on lifetime. From the open-circuit voltage drop (see Fig. 2a) [6], it was found that the lifetime of nonequilibrium charge carriers is $520 \mu \mathrm{s}$.

The results of studying the spectral dependence of the quantum efficiency (Fig. 3, curve 1) show that the spectral range of photosensitivity of the $\mathrm{SC}$ is 0.42 $1.20 \mu \mathrm{m}$ [12]. The maximum value of $Q(\lambda)$ is observed in the spectral range from 0.90 to $1.10 \mu \mathrm{m}$, and starting from $0.80 \mu \mathrm{m}, Q(\lambda)$ noticeably decreases. 
Table 1 - Output parameters and light diode characteristics of the $\mathrm{SC}$ obtained as a result of experiment and simulation

\begin{tabular}{|c|c|c|c|c|}
\hline \multirow{2}{*}{ Parameters } & \multirow{2}{*}{$\begin{array}{c}\text { Exper- } \\
\text { imental } \\
\text { sample }\end{array}$} & \multicolumn{3}{|c|}{ Modeling the influence of } \\
\cline { 3 - 5 } & 39.0 & 39.0 & 43.1 & 43.1 \\
\hline$J_{S C, \mathrm{~mA} / \mathrm{cm}^{2}}$ & $\boldsymbol{J}_{\mathbf{0}}$ & $\boldsymbol{J}_{\boldsymbol{P H}}$ & $\begin{array}{c}\boldsymbol{J}_{\boldsymbol{P H}} \text { and } \\
\boldsymbol{J}_{\mathbf{0}}\end{array}$ \\
\hline$U_{O C}, \mathrm{mV}$ & 578 & 643 & 583 & 658 \\
\hline$F F$, rel. un. & 0.80 & 0.82 & 0.80 & 0.82 \\
\hline$\eta, \%$ & 18.1 & 20.4 & 20.1 & 23.1 \\
\hline$J_{P H}, \mathrm{~mA} / \mathrm{cm}^{2}$ & 38.8 & 39.0 & 43.1 & 43.1 \\
\hline$R_{S}, \mathrm{Ohm} \mathrm{cm}{ }^{2}$ & 0.45 & 0.45 & 0.45 & 0.45 \\
\hline$R_{S H}, \mathrm{Ohm} \mathrm{cm}{ }^{2}$ & 1013 & 1013 & 1013 & 1013 \\
\hline$A, \mathrm{rel} . \mathrm{un}$. & 0.9 & 0.9 & 0.9 & 0.9 \\
\hline$J_{0}, \mathrm{~A} / \mathrm{cm}^{2}$ & $5.4^{2} \cdot 10^{-13}$ & $3.1 \cdot 10^{-14}$ & $5.4 \cdot 10^{-13}$ & $3.1 \cdot 10^{-14}$ \\
\hline
\end{tabular}

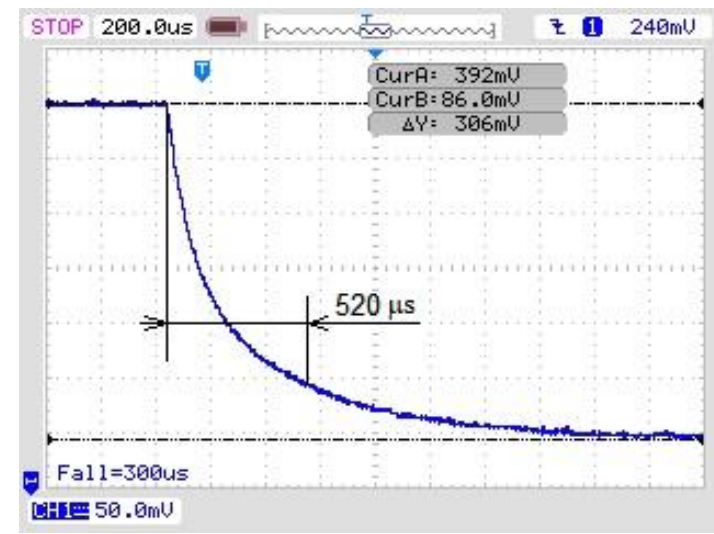

a

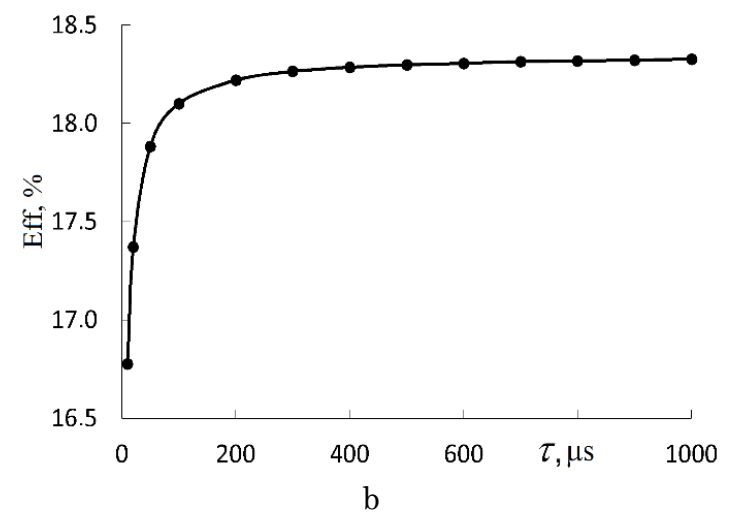

Fig. 2 - Investigation of the lifetime of nonequilibrium charge carriers in industrial samples of SCs made in China (a) and modeling the effect of the lifetime on their efficiency (b)

\subsection{Modeling the Influence of the Lifetime of Nonequilibrium Charge Carriers on the Efficiency of Industrial Silicon SCs}

Since the value of the efficiency of the investigated industrial samples of Chinese production was inferior to the efficiency of the best industrial samples of European production, which exceeds $20 \%$, then to find ways to increase the efficiency, a numerical simulation of the parameters of the investigated SCs was carried out using a PC. For the simulation, the freely available PC1D 5.9 software developed at the University of New South Wales (Australia) was used [13]. With the help of this software, an electronic model of the SC was created. The parameters of the base silicon crystal of the SC,

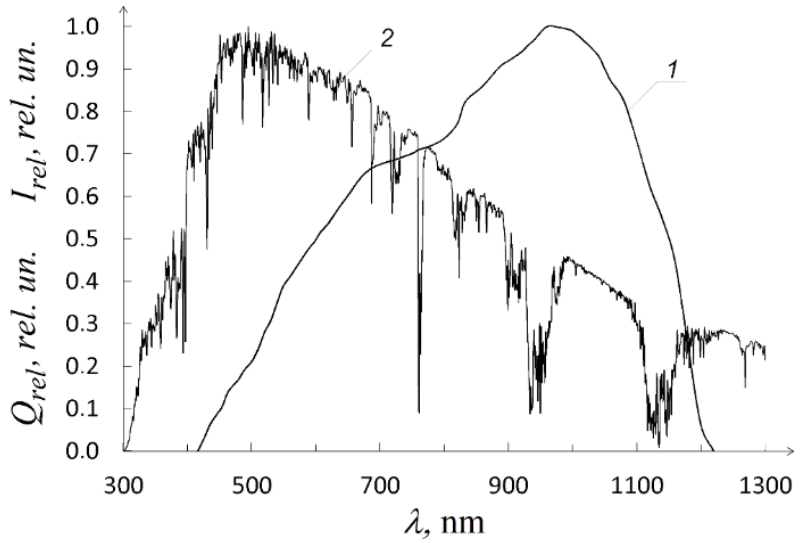

Fig. 3 - Spectral dependences of the quantum efficiency of a Chinese-made SC: $1-Q(\lambda)$ SC; 2 - solar spectrum AM1.5G

such as band gap, relative permittivity, intrinsic concentration of charge carriers, mobility of electrons and holes were included in the PC1D 5.9 software. In addition, the following characteristics of the investigated SC were taken into account in the modeling:

- the doping level of the base $p$-type crystal which is $1.5 \cdot 10^{16} \mathrm{~cm}^{-3}$;

- the thickness of the $n^{+}$-layer is $0.1 \mu \mathrm{m}$ and of the $p^{+}$-layer $-1.15 \mu \mathrm{m}$, the average level of their alloying at erfc-distribution is $10^{20} \mathrm{~cm}^{3}$ and $10^{18} \mathrm{~cm}^{3}$, respectively;

- the thickness of the antireflection coating made of $\mathrm{Si}_{3} \mathrm{~N}_{4}$ is $53 \mathrm{~nm}$;

- the relief height of the chaotically textured frontal surface is 3 microns;

- recombination rates on the front and back surfaces $S_{n}=S_{p}=10^{3} \mathrm{~m} / \mathrm{s}$;

- series and shunt resistances, which were determined by analytical processing of the experimental light CVC (Table 1).

The simulation of the $\mathrm{SC}$ operation was carried out for a temperature of $25^{\circ} \mathrm{C}$ in the $\mathrm{AM} 1.5 \mathrm{G}$ irradiation mode at a front surface illumination of $1000 \mathrm{~W} / \mathrm{m}^{2}$. The variable parameter in the model was the minority carrier lifetime, which varied from 10 to $1000 \mu \mathrm{s}$.

Analysis of the data obtained (Fig. 2b) shows that, starting from the values of the lifetime of $300 \mu$ s [14], its further increase does not affect the efficiency. Since the experimental value of the lifetime for the investigated industrial samples of SCs was $520 \mu \mathrm{s}$, this indicates that the quality of the base crystal is not a factor limiting the efficiency of the investigated SCs at a level of $18 \%$.

\subsection{Modeling the Influence of the Light Diode Characteristics on the Efficiency of Industrial Silicon SCs}

Analyzing expression (1), it can be shown that with increasing $J_{P H}, R_{S H}$ and with decreasing $J_{0}, A, R_{S}$ the efficiency of the SC increases. However, to identify the physical mechanisms that determine the efficiency of SCs, it is more useful to establish a quantitative relationship between the efficiency of the device structure and its light diode characteristics [15-17]. This makes it possible to determine the dominant light diode characteristics, a change in which with a change in the DTS 
of the SC causes a change in its efficiency. As a result, it becomes possible to significantly reduce the volume of subsequent experimental studies to establish the physical laws of the effect of DTS on the efficiency of SCs. Therefore, in this work, using the developed computer program, we simulated the effect of changing each of the light diode characteristics of the SC on the efficiency. In this case, all the light diode characteristics of the SC, except one, are fixed, and this light diode characteristic takes on a value from the selected interval. Based on a set of light diode characteristics, in accordance with expression (1), the program calculates the theoretical light CVC and determines the efficiency. Then the next value of the light diode characteristic from the selected interval is selected and the next theoretical light CVC is calculated, from which the efficiency is determined. As a result, we get the theoretical dependence of the efficiency on the change in the selected range of one diode characteristic with the rest fixed. This simulation is repeated for each light diode characteristic of the SC. Analyzing the theoretical dependences of the efficiency on the change in the light diode characteristics, we evaluated the quantitative contribution of the change in each of the light diode characteristics to the possibility of achieving an efficiency over $20 \%$.

The simulation results show that an increase in the shunt resistance and a decrease in the series resistance with the remaining diode characteristics fixed for a SC with an efficiency of $18.1 \%$ do not lead to a significant increase in the efficiency (Fig. 4a, b) [18, 19]. Thus, an increase in the shunt resistance from $R_{S H}=1000$ to $R_{S H}=4000 \mathrm{Ohm} \cdot \mathrm{cm}^{2}$ leads to an increase in efficiency by $0.1 \%$. A decrease in the series resistance from $R_{S}=0.45$ to $R_{S}=0.1 \mathrm{Ohm} \cdot \mathrm{cm}^{2}$ leads to an increase in efficiency by $0.5 \%$.

A significant increase in efficiency with the remaining diode characteristics fixed can be achieved either by increasing the photocurrent density or by decreasing the diode saturation current density (Fig. 4c, d) [20, 21]. Thus, an increase in the photocurrent density by a factor of 1.1, from $J_{P H}=39.0$ to $J_{P H}=43.1 \mathrm{~mA} / \mathrm{cm}^{2}$, leads to an increase in efficiency up to $20.1 \%$ (Table 1 , Fig. 1). A decrease in the density of the diode saturation current from $J_{0}=5.4 \cdot 10^{-13}$ to $J_{0}=3.1 \cdot 10^{-14} \mathrm{~A} / \mathrm{cm}^{2}$ allows to increase efficiency up to $20.4 \%$ (Table 1 , Fig. 1) [21]. Mathematical modeling showed that the simultaneous growth of $J_{0}=3.1 \cdot 10^{-14} \mathrm{~A} / \mathrm{cm}^{2}$ and $J_{P H}=43.1 \mathrm{~mA} / \mathrm{cm}^{2}$ leads to an increase in efficiency up to $23.1 \%$ (Table 1, Fig. 5).

According to the experimental data (Fig. 3), the shortwavelength limit of photosensitivity of the studied SC samples is $0.42 \mu \mathrm{m}$; therefore, the ultraviolet part of the spectrum is not converted in the device structures. So, an increase in the photocurrent density for the investigated SC can be obtained by applying a luminescent coating to the surface of the finished device structure. This coating absorbs photons in the ultraviolet part and generates photons in the infrared part of the solar spectrum $[22,23]$. The luminescent coating based on lead sulfide quantum dots applied by an economical chemical method is the most optimal for industrial design of SCs made in China $[24,25]$. Such quantum dots
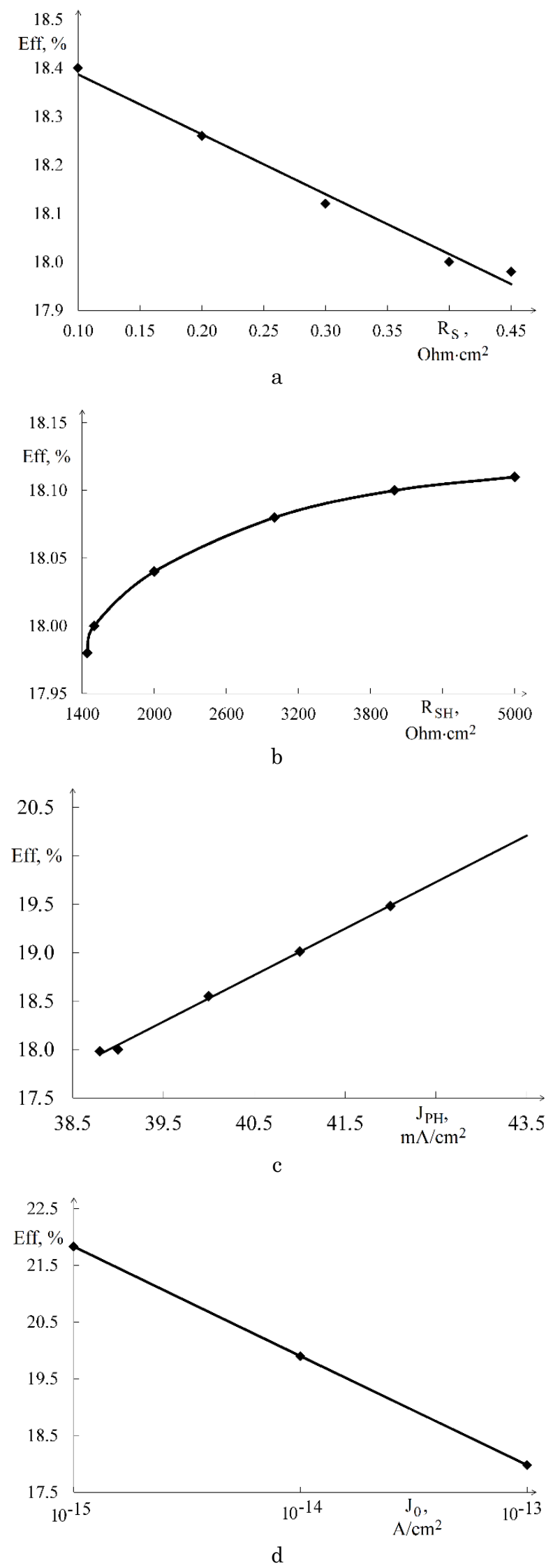

Fig. 4 - Modeling the influence of series resistance (a), shunt resistance (b), photocurrent density (c) and diode saturation current density (d) on the efficiency of a Chinese-made Si-SC 
absorb light in the spectral range $0.30-0.40 \mu \mathrm{m}$ and generate photons with a length of about $1.05 \mu \mathrm{m}$ [24], which corresponds to the region of maximum experimental values of the quantum efficiency investigated in the SC (Fig. 3). According to the simulation results presented in [24], the use of such luminescent coatings theoretically makes it possible to increase the initial short-circuit current density by more than 1.1-1.2 times, which, according to the results of our studies, is sufficient to achieve an efficiency of over $20 \%$.
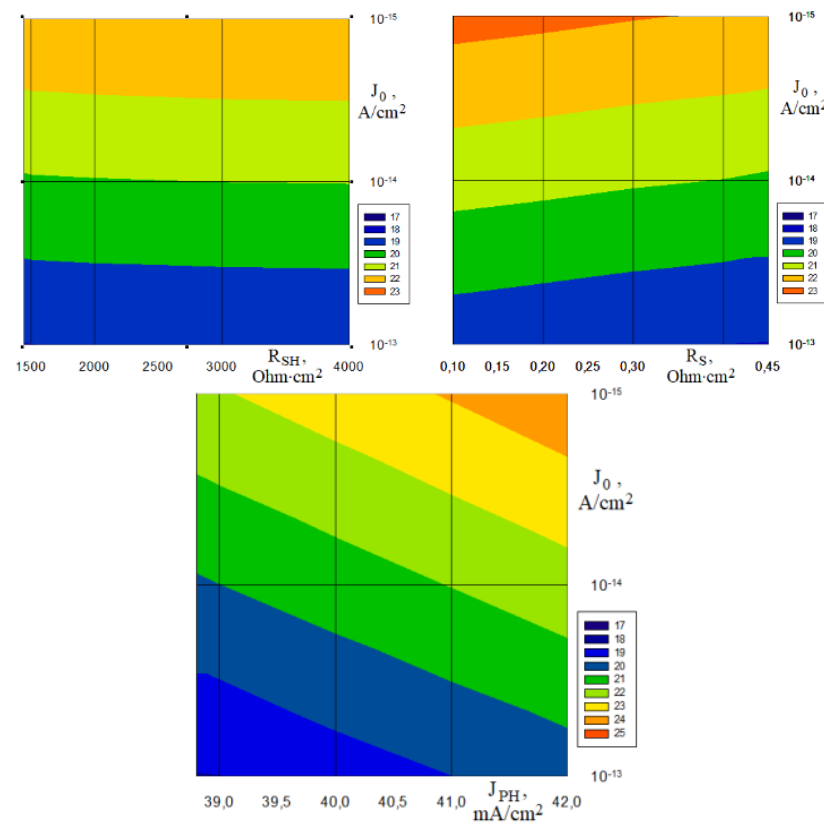

Fig. 5 - Diagrams of the efficiency distribution of the investigated PVs constructed based on the modeling results

\subsection{Experimental Advancement of Temperature Effect on the Input Parameters and Light Characteristics of Industrial Silicon SCs}

Analysis shows that an almost linear decrease in efficiency occurs with increasing temperature (Fig. 6a) [26]. The reduction factor, which describes the relative change in efficiency for one degree change in temperature, is $0.7 \% /{ }^{\circ} \mathrm{C}$. For the open-circuit voltage and short-circuit current density, there is also a decrease in their values with increasing operating temperature (Fig. 6b, c). It was experimentally found that the fill factor of the light CVC practically does not change with increasing temperature.

Analysis of the light-emitting diode characteristics shows that the recorded decrease in efficiency is due to an increase in the diode saturation current density (Fig. 7a) and a decrease in shunt resistance (Fig. 7b).

The obtained experimental results can only be partially commented within the framework of traditional ideas about the influence of temperature on efficiency of photovoltaic processes in SC, which are summarized in [27]. According to the traditional view, which corresponds to the experimental study of SCs with increasing temperature, the diffusion length of nonequilibrium carriers in $\mathrm{Si}$ increases. This is because the diffusion coefficient does not change or increase, and lifetime of minority carriers increases with increasing temperature.
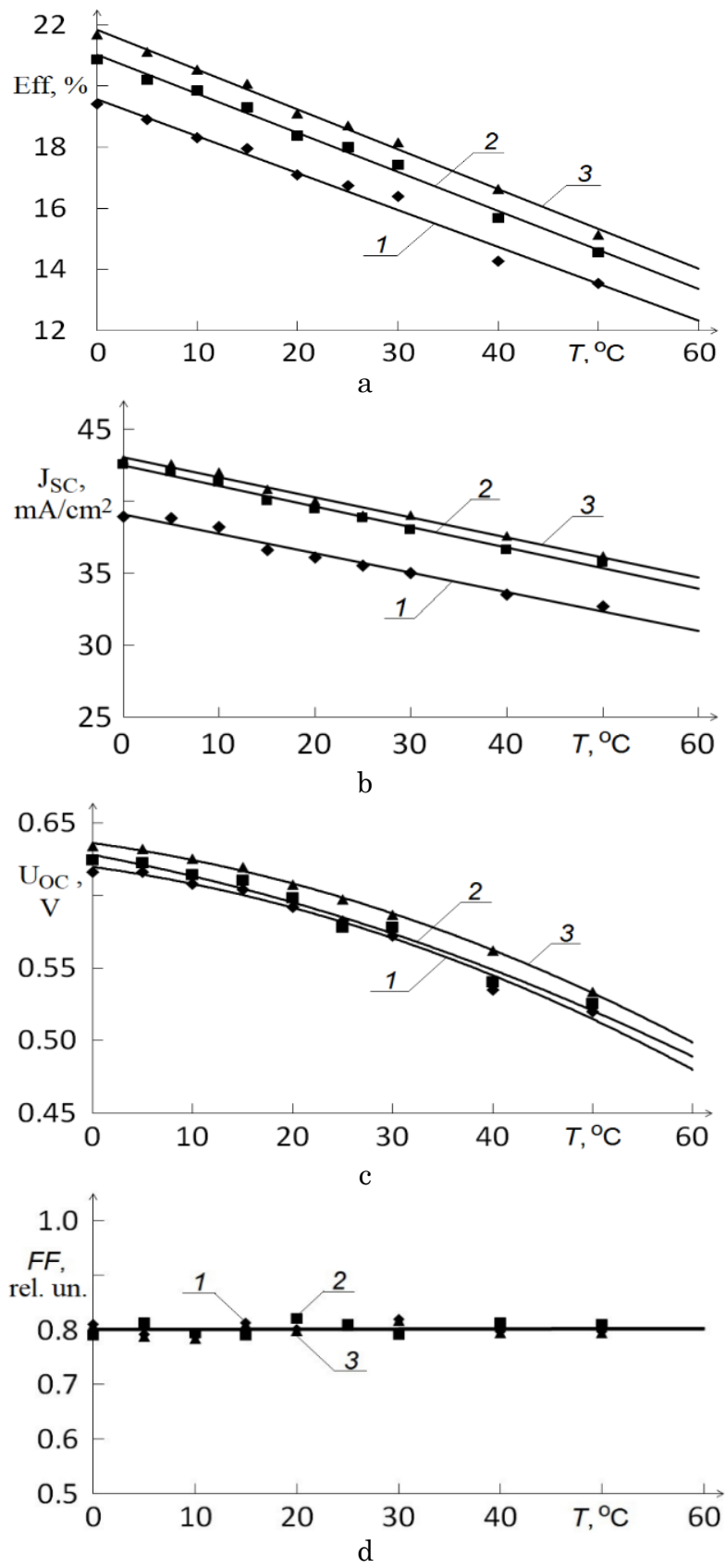

Fig. 6 - Influence of operating temperature on efficiency (a), short-circuit current density (b), open-circuit voltage (c) and light CVC filling factor (d) of the investigated SC: sample 1 with efficiency $=16.7 \%$ at a temperature of $25^{\circ} \mathrm{C}$; sample 2 with efficiency $=18.1 \%$ at a temperature of $25^{\circ} \mathrm{C}$; sample 3 with an efficiency $=18.7 \%$ at a temperature of $25^{\circ} \mathrm{C}$

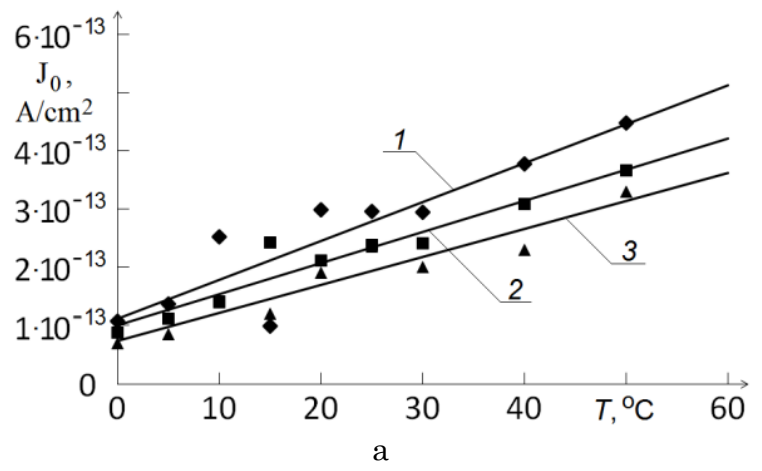



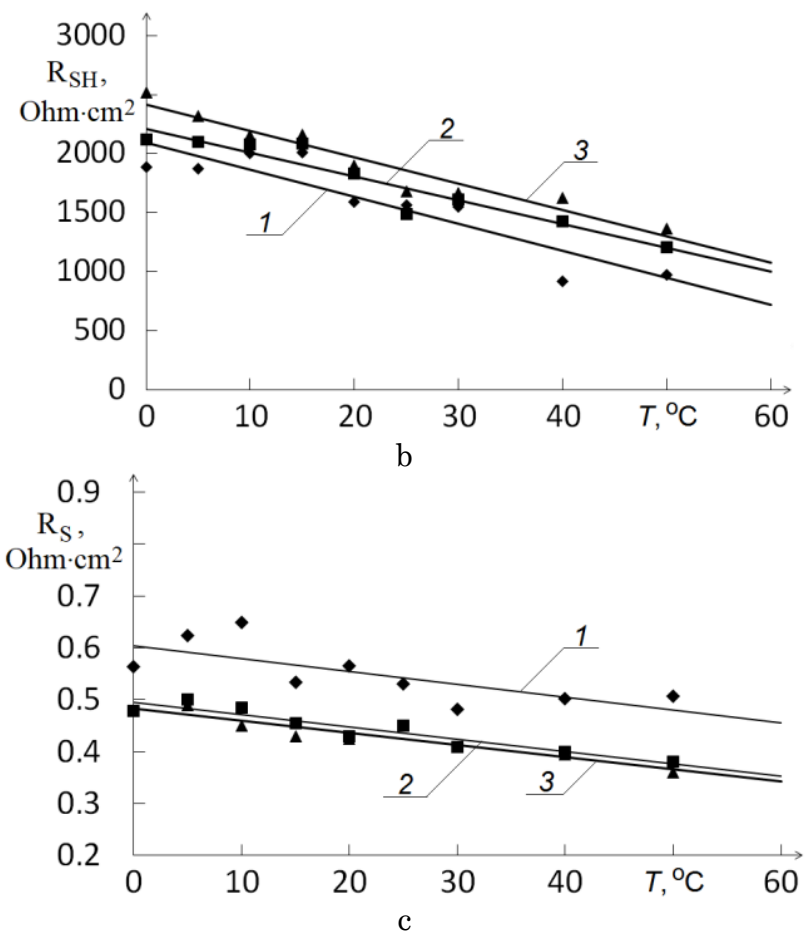

Fig. 7 - Influence of operating temperature on diode saturation current density (a), shunt (b) and serial (c) resistances of the investigated Si-SC: sample 1 with efficiency $=16.7 \%$ at a temperature of $25^{\circ} \mathrm{C}$; sample 2 with efficiency $=18.0 \%$ at a temperature of $25^{\circ} \mathrm{C}$; sample 3 with an efficiency $=18.7 \%$ at a temperature of $25^{\circ} \mathrm{C}$

An increase in the diffusion length of minority carriers leads to an increase in the short-circuit current density with increasing temperature. However, this effect is insignificant and amounts to about $0.07 \% /{ }^{\circ} \mathrm{C}$. The decrease in the open-circuit voltage significantly exceeds the increase in the short-circuit current density and is $0.4 \% /{ }^{\circ} \mathrm{C}$. A smoother form of the light $\mathrm{CVC}$ curve at elevated temperatures leads to a decrease in the filling factor of the light CVC curve. Therefore, in general, an increase in temperature leads to a relative decrease in efficiency by $0.5 \% /{ }^{\circ} \mathrm{C}$.

According to the obtained experimental data for the $\mathrm{SC}$ of Chinese production, the relative decrease in efficiency is higher and is $0.7 \% /{ }^{\circ} \mathrm{C}$. In this case, the shortcircuit current density decreases, and the filling factor of the light CVC characteristics does not change.

According to the existing physical concepts, the diode saturation current density is the most important light-emitting diode characteristic, which controls the change of the output parameters of the SC when the operating temperature changes. Without taking into account the shunt and series resistances, the theoretical expression for the diode saturation current density has the form [2]:

$$
J_{O}=C \cdot T^{3} \cdot \exp \cdot\left(-q E_{g} / k T\right),
$$

where $C$ is a parameter that changes at operating temperature $T, q$ is the electron charge, $E_{g}$ is the band gap.

In this work, it was shown that at $C \cdot T^{3}=1.5 \cdot 10^{5}$ $\mathrm{A} \cdot \mathrm{cm}^{-2}$ the best correspondence between experimental temperature changes of the initial parameters and their theoretical dependences is observed. Since $C \cdot T^{3}$ is a constant, the exponential increase in the diode saturation current density indicates that the main physical mechanism of increasing $J_{0}$ is a thermally activated increase in the concentration of charge carriers. Since the experimental dependences $J_{0}(T)$ are not linearized in the coordinates $\ln J_{0}-1000 / T$, the above mechanism is not the only one. Its existence is indicated by the recorded experimental unconventional decrease in the short-circuit current density with increasing operating temperature.

Analysis of the diode characteristics shows that an abnormally high decrease in efficiency and an unconventional decrease in the short-circuit current density are due to the recorded experimental decrease in the shunt resistance. Current in areas of high conductivity reduces the contribution of photocurrent to the shortcircuit current and is an additional physical mechanism that reduces efficiency. Modeling the effect of an increase in the diode saturation current density and a decrease in the shunt resistance (Fig. 7a, b) showed that they are proportional.

Since during the research a high rate of reduction of the efficiency of SCs made in China was experimentally established, this in operation eliminates their relatively high initial parameters and determines the feasibility of their use in a photovoltaic thermal module (PV/T), which is a hybrid of an SC and a solar collector and allows due to the circulation of heat carriers to provide cooling of the silicon device structure. Depending on the necessary technological requirements, three main modes of PV/T operation are developed [4]: ensuring the most efficient generation of electricity, ensuring the maximum efficiency of thermal energy and ensuring the maximum total efficiency. In [4], designs were developed that provide maximum heat output from the front surface of the PV/T to the environment and from the rear side to the coolant circuit to ensure maximum electric power. The main design feature of the module corresponding to this mode of operation is the absence of an air gap between the SC and the translucent coating $[28,29]$. In this mode of operation, the temperature of the coolant in the circuit should not exceed $35^{\circ} \mathrm{C}$. But since the liquid heated by the module has a low temperature, it requires further heating, which leads to the need for additional equipment. For example, this mode of operation of PV/T provides a combined system of hot water supply, heating and air conditioning based on heat pump and PV/T.

\section{CONCLUSIONS}

It was shown that the lifetimes of nonequilibrium charge carriers, which are $520 \mu \mathrm{s}$, realized for Chinesemade SC industrial samples, do not limit the possibility of increasing their efficiency by more than $20 \%$. The achieved values of series and shunt resistances of industrial SC samples of Chinese production, which are $0.45 \mathrm{Ohm} \mathrm{cm}^{2}$ and $1000 \mathrm{Ohm} \mathrm{cm}^{2}$, respectively, do not need further optimization. It was also shown that the increase in photocurrent density from 39.0 to $43.1 \mathrm{~mA} / \mathrm{cm}^{2}$ in industrial samples of Chinese-made SCs without changing other diode characteristics leads to an increase in their efficiency up to $20.1 \%$. For such an increase in the photocurrent density on the surface 
of the finished device structure, it is necessary to form luminescent coatings containing lead sulfide quantum dots. It was found that a decrease in the diode saturation current density from $5.4 \cdot 10^{-13}$ to $3.1 \cdot 10^{-14} \mathrm{~A} / \mathrm{cm}^{2}$ in industrial SC designs made in China without changing other diode characteristics leads to an increase in efficiency up to $20.4 \%$. Possible physical and technological approaches to reduce the diode saturation current density of finished SCs are the deposition of plasmonic coatings or the processing of device structures in a magnetic field. A simultaneous increase in the photocurrent density and the diode saturation current density to the above values makes it possible to increase the efficiency up to $23.1 \%$.

A study of the effect of the operating temperature on the efficiency of silicon SCs made in China showed that with increasing operating temperature, the decrease in efficiency is $0.07 \% /{ }^{\circ} \mathrm{C}$, which is significantly higher than that of design structures of European and domestic production and due to unconventional short circuit current density. The identified temperature dependence of the efficiency indicates the advisability of using SCs of the Chinese production in the design of a photoelectric thermal installation that, together with a heat pump, is part of a combined system of hot water supply, heating and conditioning.

\title{
REFERENCES
}

1. K. Sopian, S.L. Cheow, S.H. Zaidi, AIP Conf. Proc. 1877, 020004 (2017).

2. A. Rehman, S.H. Lee, Scientific World J. 2013, 470347 (2013).

3. S. Binetti, M. Acciarri, A. Donne, M. Morgano, Y. Jestin, Int. J. Photoenergy 2013, 249502 (2013).

4. R.V. Zaitsev, M.V. Kirichenko, G.S. Khrypunov, et. al., 2017 IEEE First Ukraine Conference on Electrical and Computer Engineering, 360 (Ukraine, Kyiv: 2017).

5. G. Bye, B. Ceccaroli, Sol. Energy Mater. Sol. C. 130, 634 (2014).

6. M.V. Kirichenko, R.V. Zaitsev, V.R. Kopach, Telecommun. Radio Eng. 69 No 5, 441 (2010).

7. H.S. Raushenbach, Solar Cells Array Design (New York: Litton Uducation Publishing: 1980).

8. K.A. Minakova, R.V. Zaitsev, J. Nano- Electron. Phys. 12 No 4, 04028 (2020).

9. R. Abbassi, A. Abbassi, M. Jemli, S. Chebbi, Renew. Sustain. Energy Rev. 90, 453 (2018).

10. A.M. Beigi, A. Maroosi, Sol. Energy 171, 435 (2018).

11. M.A. Elaziz, D. Oliva, Energy Conversion and Management 171, 1843 (2018).

12. G.S. Khrypunov, V.R. Kopach, A.V. Meriuts, R.V. Zaitsev, M.V. Kirichenko, N.V. Deyneko, Semiconductors 45, 1505 (2011).

13. G. Hashmi, A.R. Akand, M. Hoq, H. Rahman, Silicon 10, 1653 (2018).

14. R.V. Zaitsev, V.R. Kopach, M.V. Kirichenko, E.O. Lykyanov, G.S. Khrypunov, V.N. Samofalov, Functional Mater. 17 No 4, $554(2010)$.

15. J. Haschke, O. Dupré, M. Boccard, C. Ballif, Sol. Energy Mater. Sol. C. 187, 140 (2018).

16. Y. Liu, Y. Li, Y. Wu., G. Yang, L. Mazzarella, P. Procel-Moya, A.C. Tamboli, K. Weber, M. Boccard, O. Isabella, X. Yang,

B. Sun, Mater. Sci. Eng. R: Rep. 142, 100579 (2020).

17. L.C. Andreani, A. Bozzola, P. Kowalczewski, M. Liscidini, L. Redorici, Adv. Phys. X 4 No 1, 125 (2019).

18. Ya.V. Scherback, O.A. Plakhtiy, V.P. Nerubatskiy, Technical Electrodynamics 6, 26 (2017).

19. O. Savchenko, O. Miroshnyk, S. Diubko, Adv. Elect. Elect. Eng. 17 No 2, 106 (2019).

20. H. Fathabadi, J. Mater. Sci.: Mater. Electron. 30, 17314 (2019).

21. E. Sokol, V. Zamaruiev, S. Kryvosheev, et. al., 2017 IEEE First Ukraine Conference on Electrical and Computer Engineering, 432, (Ukraine, Kyiv: 2017).

22. E.V. Manzhelii, S.B. Feodosyev, I.A. Gospodarev, E.S. Syrkin, K.A. Minakova, Fiz. Nizk. Temp. 41 No 7, 718 (2015).

23. V.V. Eremenko, V.A. Sirenko, I.A. Gospodarev, E.S. Syrkin, S.B. Feodosyev, I.S. Bondar, A. Feher, K.A. Minakova, Low Temp. Phys. 43 No 11, 1323 (2017).

24. G.V. Shcherbatyuk, R.H. Inman, C. Wang, R. Winston, S. Ghosh, Appl. Phys. Lett. 96, 191901 (2010).

25. V.V. Eremenko, V.A. Sirenko, I.A. Gospodarev, E.S. Syrkin, S.B. Feodosyev, I.S. Bondar, S.S. Saxena, A. Feher, K.A. Minakova, Low Temp. Phys. 42, 99 (2016).

26. P. Singh, N.M. Ravindra, Sol. Energy Mater. Sol. C. 101, 36 (2012).

27. R. Zaitsev, M. Kirichenko, G. Khrypunov, et. al., 2nd Ukraine Conference on Electrical and Computer Engineering, 582 (Ukraine, Lviv: 2019).

28. H. Fayaz, R. Nasrina, N.A. Rahim, M. Hasanuzzaman, Sol. Energy 169, 217 (2018).

29. A.H.A. Al-Waeli, M.T. Chaichan, K. Sopian, H.A. Kazem, H.B. Mahood, A.A. Khadom, Sol. Energy 177, 178 (2019).

\section{Аналіз механізмів підвищення ефективності промислових кремніевих сонячних батарей}

\author{
М.В. Кіріченко ${ }^{1}$, Р.В. Зайцев ${ }^{1}$ К.О. Мінакова ${ }^{1}$ О.М. Чугай ${ }^{2}$, \\ С.В. Олійник ${ }^{2}$ С.Ю. Білик ${ }^{1}$, Б.О. Стисло ${ }^{1}$
}
1 Національний технічний університет "Харківський політехнічний інститут», вул. Кирпичова 2, 61002 Харків, Україна
2 Національний аерокослічний університет "Харківський авіаційний інститут", вул. Чкалова, 17, 61000 Харків, Україна

\begin{abstract}
Досліджено можливості підвищення ефективності понад 20 \% для кремнієвих фотоелектричних перетворювачів китайського виробництва. Методом комп'ютерного моделювання встановлено, що реалізовані в таких фотоелектричних перетворювачах часи життя нерівноважних носіїв заряду, які складають 520 мкс, не обмежують можливість збільшення їх ККД понад $20 \%$. Показано, що збільшення густини фотоструму до $43,1 \mathrm{~mA} / \mathrm{cm}^{2}$ призводить до зростання ККД до $20,1 \%$, а зниження густини діодного струму насичення до $3,1 \cdot 10^{-14} \mathrm{~A} / \mathrm{cm}^{2}$ зумовлюе зростання ККД до $20,4 \%$. Одночасна зміна цих діодних характеристик призводить до збільшення ККД до $23,1 \%$. У роботі пропонуються фізикотехнологічні підходи для збільшення густини фотоструму і зменшення густини діодного струму наси-
\end{abstract}


чення в готових фотоелектричних перетворювачах. У статті проведено дослідження впливу робочої температури на ефективність кристалічних кремніевих фотоелектричних перетворювачів. Показано, що зі зростанням робочої температури відносне зниження ККД монокристалічних приладів становить - 0,7 відн. \%/C, що істотно вище, ніж в приладових структурах европейського виробництва і обумовлено нетрадиційним зниженням густини струму короткого замикання. Математичне моделювання впливу світлових діодних характеристик на ККД кристалічних кремнієвих сонячних елементів показало, що зменшення ефективності приладових структур при збільшенні робочої температури обумовлено не тільки зростанням густини діодного струму насичення з $10^{-13}$ до $3 \cdot 10^{-13}$ А, що складае $300 \%$, але й зниженням шунтуючого опору з 2,5 до 1,5 кОм. Дослідження впливу робочої температури на діодний струм насичення показало, що висота потенційного бар'єру в досліджених кремнієвих фотоелектричних перетворювачах складае $0,87 \mathrm{eB}$, що обумовлено недостанім рівнем легування базового матеріалу. Обмеженість висоти потенційного бар'еру призводить до нетрадиційного зниження електроопору, що шунтуе, при збільшенні робочої температури.

Ключові слова: Кремній, Фотоелектричні перетворювачі, Сонячна енергія, PV/T системи, Електричні параметри, Ефективність, Моделювання, Оптимізація. 